Ефименко С.В.

\title{
Управление самостоятельной работой студентов технического вуза
}

В статье отражены результаты психолого-педагогического исследования самостоятельной работы студентов технического вуза, основной челью которого являлось выявление инструментария управления выше указанного вида работы студентов и его описания относительно психологических возможностей трёх категорий студентов («широко предметно ориентированных», «узко предметно ориентированных», «предметно неориентированных») и особенностей иноязычной коммуникативной учебно-профессиональной деятельности в техническом вузе.

Ключевые слова: регулирование самостоятельной работы студентов, уровень готовности студентов к самостоятельной работе, предъявление системы знаний для самостоятельной работы, взаимодействие преподавателя и студентов, контроль усвоения содержания учебной дисциплины.

В последнее десятилетие на рынке труда востребованы специалисты, обладающие готовностью к самообразованию и самосовершенствованию, так как осуществляется переход от модели «образование на всю жизнь» к парадигме «образование через всю жизнь». Самостоятельная работа на занятиях по немецкому языку является средством формирования у студентов активности и самостоятельности как черт личности, поэтому проблема эффективного управления самостоятельной работой студентов на старших ступенях бакалавриата (III-IV курсах) в техническом вузе является особенно актуальной в наши дни. В последнее время на старших ступенях бакалавриата (III-IV курсах) в технических вузах России акцент переносится на самостоятельные виды деятельности студентов, увеличивается количество часов, отводимых на этот вид деятельности, но при этом многие студенты испытывают значительные трудности при самостоятельном выполнении многих видов иноязычной коммуникативной учебно-профессиональной деятельности. В связи с этим концепция самостоятельной работы студентов находится сегодня в стадии существенного переосмысления.

Исследованием самостоятельной работы студентов в отечественной психологии занимались многие видные психологи и педагоги, такие как И.З. Гликман, Т.А. Ильина, А.Г. Казакова, М.И. Махмутова, П.И. Пидкасистый, Е. С. Полат, В. В. Шаламов и многие другие. Самостоятельная работа - особый вид фронтальной, групповой и индивидуальной учебной деятельности учащихся, осуществляемой под руководством, но без непосредственного участия преподавателя, характеризуемой большой активностью протекания познавательных процессов и выполняемой как на занятии, так и во вне занятий, и служащей средством повышения эффективности процесса обучения и подготовки учащихся к самостоятельному пополнению своих знаний [8]. Самостоятельная работа может быть определена как целенаправленная, внутренне мотивированная, 
структурированная самим субъектом в совокупности выполняемых действий и корригируемая им по процессу и результату деятельность [4]. Активность личности и способность к осознанной саморегуляции деятельности являются, в свою очередь, необходимыми условиями успешного выполнения самостоятельной работы студентами технического вуза. По данным Н.С. Лейтеса, активность и саморегуляция - «универсальные внутренние условия осуществления деятельности и необходимые предпосылки развития как общих, так и специальных способностей» [5, с. 53]. Саморегуляция психической активности понимается А.К. Осницким как «системно организованный психический процесс по инициации, построению, поддержанию всех видов и форм внешней и внутренней активности, которые направлены на достижение принимаемых субъектом целей, и управлению ими» [6, с. 15].

С позиций системного подход к управлению качеством образовательного процесса (Ф.Ф. Королёв, Н.В. Кузьмина, В.В. Монахов, О.П. Околелов, В.К. Шаповалов) регулирование самостоятельной работы студентов по иностранному языку включает несколько циклов: «установление уровня готовности студентов к самостоятельной работе; предъявление системы знаний для самостоятельной работы; взаимодействие преподавателя и студентов; контроль усвоения содержания учебной дисциплины» [7, с. 95].

Готовность к самостоятельной деятельности (Б.Г. Ананьев, Б.Ф. Райский, А.Я. Коломенский, В.А. Сластёнин) - это интегративное образование личности, выступающее как качественная динамическая характеристика эффективности подготовки учащегося, представленная единством мотивационных, содержательных и процессуальных компонентов. Мотивационный компонент готовности к самостоятельной деятельности означает отношение учащегося к самостоятельной деятельности, наличие интереса к обучению. Содержательный компонент готовности к самостоятельной деятельности включает теоретическую подготовку студентов, анализ студентом своей учебной деятельности. Процессуальный компонент готовности к самостоятельной деятельности состоит из умений студентов получать и использовать знания из источников и способностей учащихся по самоорганизации и саморегуляции самостоятельной деятельности [1]. Для определения уровня готовности к самостоятельной работе у студентов, изучающих немецкий язык на старших ступенях (III-IV курсах) бакалавриата в техническом вузе, был разработан соответствующий опросник «Диагностика уровня готовности к самостоятельной работе при изучении немецкого языка в техническом вузе». Данный опросник был проверен на ретестовую надёжность на основе коэффициента произведения моментов Пирсона. Далее группа независимых экспертов проверила рассматриваемый опросник на содержательную валидность [2]. В процессе разработки опросник несколько раз корректировался. Данные, полученные при помощи опросника «Диагностика уровня готовности к самостоятельной работе при изучении немецкого языка в техническом вузе», были распределены в соответствии с тремя категориями 
студентов: «широко предметно ориентированными», «узко предметно ориентированными» и «предметно неориентированными», объём выборки которых составил (282 человека). При помощи критерия «мотивация обучения в вузе» 282 студента технического вуза были классифицированы на три категории: «широко предметно ориентированные» (69 человек), «узко предметно ориентированные» (112 человек) и «предметно неориентированные» (101 человек). «Широко предметно ориентированные» являются студентами, одинаково хорошо успевающими по всем предметам, и у них высокая мотивация обучения в техническом вузе. «Узко предметно ориентированные» успевают только по тем предметам, которые необходимы им для их будущей профессиональной деятельности. «Предметно неориентированные» стремятся приобрести диплом при формальном усвоении знаний.

При работе с авторским опросником «Диагностика уровня готовности к самостоятельной работе при изучении немецкого языка в техническом вузе» «широко предметно ориентированные» набирают большое количество баллов (60-48 баллов) по вопросам, характеризующим высокий уровень готовности к самостоятельной работе. То есть для «широко предметно ориентированных» характерно общеличностное развитие в плане совершенствования целеполагания, самосознания, рефлексивности мышления, самодисциплины, и у этой категории студентов уже сформирована положительная мотивация к изучению немецкого языка в техническом вузе. У «узко предметно ориентированных»средний уровень готовности к самостоятельной работе, о чём свидетельствуют высокие баллы (60-48 баллов), поставленные по тем вопросам опросника, которые характеризуют уровень готовности к самостоятельной работе как средний. Таким образом «узко предметно ориентированные» испытывают определённые затруднения при выполнении самостоятельной работы. Они не всегда точно представляют цель как конечный результат самостоятельной работы, не всегда способны увидеть ошибки в процессе выполнения самостоятельной работы, у них не сформированы на достаточно высоком уровне волевые качества. Высокие баллы (60-48 баллов) «предметно неориентированные» отдают пунктам для низкого уровня сформированности готовности к выполнению самостоятельной работы. У «предметно неориентированных» - отрицательная мотивация к изучению немецкого языка в техническом вузе, не говоря уже о способностях моделировать самостоятельную деятельность, о соотношении полученных результатов с целью и задачами, выраженными в условиях деятельности, и о сформированности волевых качеств.

Для успешного управления самостоятельной работой студентов на старших ступенях бакалавриата (III-IV курсах) в техническом вузе был создан банк заданий для самостоятельной работы, учитывались при этом психологические возможности трёх категорий студентов и уровень готовности к самостоятельной работе. Банк заданий трёх уровней сложности был разработан на основе технических текстов для студентов, обучающихся на факультете электроники и приборостроения 
Таганрогского технологического института Южного федерального университета (ТТИ ЮФУ). При этом к техническим текстам предъявлялись следующие требования:

- учебные тексты должны содержать наиболее характерные для специальностей факультета электроники и приборостроения Таганрогского технологического института Южного федерального университета (ТТИ ЮФУ) языковые (лексические и грамматические) явления;

-логическая последовательность предъявления учебных текстов должна соответствовать процессу изучения студентами специальных дисциплин, то есть перечень учебных текстов в пособии должен согласовываться с программой подготовки специалиста, с тем чтобы профессиональная информация, процессы и явления, содержащиеся в текстах пособия, были поняты студентами;

-тексты должны выполнять задачу предоставления профессионально важной информации;

-тексты и задания к ним должны развивать умения смысловой обработки информации при чтении, а также позволять создание основы, необходимой для порождения текста в различных видах профессионально ориентированного иноязычного общения;

-тексты пособия должны быть аутентичными, отбор тем следует осуществлять по результатам бесед с преподавателями выпускающих кафедр, с учётом особенностей будущей профессиональной деятельности студентов.

На основе технических текстов и сучётом уровня готовности к самостоятельной работе был разработан представленный в таблице 1 банк заданий для самостоятельной работы трёх категорий студентов: «широко предметно ориентированных», «узко предметно ориентированных» и «предметно неориентированных».

Таблица 1

\section{Банк заданий для самостоятельной работы трёх категорий студентов}

\begin{tabular}{|c|c|c|}
\hline $\begin{array}{c}\text { «Широко предметно } \\
\text { ориентированные» }\end{array}$ & $\begin{array}{c}\text { «Узко предметно } \\
\text { ориентированные» }\end{array}$ & $\begin{array}{c}\text { «Предметно } \\
\text { неориентированные» }\end{array}$ \\
\hline $\begin{array}{l}\text { - выполнение } \\
\text { коммуникативных } \\
\text { заданий повышенного } \\
\text { уровня сложности }\end{array}$ & $\begin{array}{l}\text { - выполнение условно- } \\
\text { коммуникативных и } \\
\text { коммуникативных } \\
\text { заданий }\end{array}$ & $\begin{array}{l}\text { - выучить новые слова и } \\
\text { термины }\end{array}$ \\
\hline $\begin{array}{l}\text { - подготовка творческих } \\
\text { работ и проектов }\end{array}$ & $\begin{array}{l}\text { - изложение } \\
\text { результатов решения } \\
\text { профессионально } \\
\text { ориентированных задач } \\
\text { на немецком языке }\end{array}$ & $\begin{array}{l}\text { - разобраться } \\
\text { самостоятельно в } \\
\text { грамматическом } \\
\text { материале }\end{array}$ \\
\hline $\begin{array}{l}\text { - написание эссе, } \\
\text { делового письма на } \\
\text { немецком языке }\end{array}$ & $\begin{array}{l}\text { - подготовка рефератов, } \\
\text { докладов, сообщений }\end{array}$ & $\begin{array}{l}\text { - выполнить задания по } \\
\text { заданному алгоритму }\end{array}$ \\
\hline
\end{tabular}


Для эффективного управления самостоятельной работой студентов на старших ступенях бакалавриата (III-IV курсах) в техническом вузе необходимо также принимать во внимание формы взаимодействия преподавателя с тремя категориями студентов. Педагогическое взаимодействие или взаимодействие преподавателя со студентами - это ценностный, социально обусловленный и личностно значимый процесс реализации межличностных и деятельностных контактов студента и преподавателя (при направляющей роли преподавателя). Педагогическое взаимодействие или взаимодействие преподавателя со студентами направлено на трансляцию культуры в процессе духовно-практической деятельности преподавателя и студентов, что связано с глубинными изменениями в каждой из контактирующих сторон, в ходе и результате которых при определенных условиях осуществляется осознанное, интенсивное и продуктивное саморазвитие, самосовершенствование, самостроительство взаимодействующих субъектов [3]. Проанализировав литературу по проблеме взаимодействия преподавателя со студентами и на основе собственного опыта, были выделены и дифференцированы в соответствии с тремя категориями формы взаимодействия преподавателя со студентами.

Таблица 2

\section{Формы взаимодействия преподавателя со студентами трёх категорий}

\begin{tabular}{|c|c|c|}
\hline $\begin{array}{l}\text { «Широко предметно } \\
\text { ориентированные» }\end{array}$ & $\begin{array}{l}\text { «Узко предметно } \\
\text { ориентированные» }\end{array}$ & $\begin{array}{c}\text { «Предметно } \\
\text { неориентированные» }\end{array}$ \\
\hline $\begin{array}{l}\text { 1. Преподаватель } \\
\text { выступает в роли } \\
\text { старшего помощника. }\end{array}$ & $\begin{array}{l}\text { 1. Преподаватель } \\
\text { выступает в роли } \\
\text { наставника. }\end{array}$ & $\begin{array}{l}\text { 1. Преподаватель } \\
\text { выступает в роли } \\
\text { проводника-контролёра. }\end{array}$ \\
\hline $\begin{array}{l}\text { 2. Стиль общения - } \\
\text { демократический. }\end{array}$ & $\begin{array}{l}\text { 2. Стиль общения - } \\
\text { демократический. }\end{array}$ & $\begin{array}{l}\text { 2. Стиль общения - } \\
\text { ближе к авторитарному. }\end{array}$ \\
\hline $\begin{array}{l}\text { 3. У студентов действия } \\
\text { самоконтроля } \\
\text { автоматизированы. }\end{array}$ & $\begin{array}{l}\text { 3. Самоконтроль } \\
\text { сформирован, } \\
\text { но недостаточно } \\
\text { автоматизирован. }\end{array}$ & $\begin{array}{l}\text { 3. Самоконтроль } \\
\text { полностью не } \\
\text { сформирован. }\end{array}$ \\
\hline
\end{tabular}

Усиление познавательной активности студента, повышение эффективности его самостоятельной работы предполагают не только определённую её организацию, но и контроль. Контролируя самостоятельную работу студентов технического вуза, необходимо использовать такие методы и формы, которые не позволяют студентам чувствовать грубого давления, а воспринимаются ими как необходимая помощь и средство повышения познавательной активности. 
Таблича 3

Методы, виды и формы контроля самостоятельной работы студентов трёх категорий

\begin{tabular}{|c|c|c|}
\hline $\begin{array}{l}\text { «Широко предметно } \\
\text { ориентированные» }\end{array}$ & $\begin{array}{c}\text { «Узко предметно } \\
\text { ориентированные» }\end{array}$ & $\begin{array}{c}\text { «Предметно } \\
\text { неориентированные» }\end{array}$ \\
\hline $\begin{array}{l}\text { 1. Гибкий контроль } \\
\text { (задаётся только цель, } \\
\text { студенты должны } \\
\text { самостоятельно } \\
\text { выбрать средства и } \\
\text { способы выполнения } \\
\text { учебных задач в рамках } \\
\text { данного материала). }\end{array}$ & $\begin{array}{l}\text { 1. Относительно жёсткий } \\
\text { контроль (обозначается } \\
\text { цель, ориентиры; } \\
\text { контролируется } \\
\text { выполнение некоторых } \\
\text { операций). }\end{array}$ & $\begin{array}{l}\text { 1. Жёсткий контроль } \\
\text { (регламентируется } \\
\text { каждая учебная } \\
\text { операция). }\end{array}$ \\
\hline $\begin{array}{l}\text { 2. Промежуточный } \\
\text { контроль по окончании } \\
\text { изучения раздела или } \\
\text { модуля курса; } \\
\text { самоконтроль, } \\
\text { осуществляемый } \\
\text { студентом в процессе } \\
\text { изучения дисциплины } \\
\text { при подготовке } \\
\text { к контрольным } \\
\text { мероприятиям; } \\
\text { итоговый контроль } \\
\text { по дисциплине в виде } \\
\text { зачета или экзамена. }\end{array}$ & $\begin{array}{l}\text { 2. Промежуточный } \\
\text { контроль; самоконтроль; } \\
\text { итоговый контроль; } \\
\text { контроль остаточных } \\
\text { знаний и умений спустя } \\
\text { определенное время } \\
\text { после завершения } \\
\text { изучения дисциплины. }\end{array}$ & $\begin{array}{l}\text { 2. Текущий контроль, } \\
\text { то есть регулярное } \\
\text { отслеживание уровня } \\
\text { усвоения материала на } \\
\text { практических занятиях; } \\
\text { промежуточный } \\
\text { контроль; } \\
\text { итоговый контроль; } \\
\text { контроль остаточных } \\
\text { знаний и умений. }\end{array}$ \\
\hline $\begin{array}{l}\text { 3. Тестирование; } \\
\text { ролевые, деловые игры; } \\
\text { разработка проектов. }\end{array}$ & $\begin{array}{l}\text { 3. Выполнение } \\
\text { индивидуальных } \\
\text { творческих заданий, } \\
\text { касающихся будущей } \\
\text { профессиональной } \\
\text { деятельности; } \\
\text { тестирование; дискуссии; } \\
\text { ролевые, деловые игры; } \\
\text { разработка проектов. }\end{array}$ & $\begin{array}{l}\text { 3. Экспресс-опрос, } \\
\text { экспресс-тестирование; } \\
\text { тестирование; написание } \\
\text { рефератов, докладов. }\end{array}$ \\
\hline
\end{tabular}

Таким образом, для эффективного управления самостоятельной работой студентов на старших ступенях бакалавриата (III-IV курсах) технического вуза при изучении немецкого языка необходимо: 
-принимать во внимание уровень готовности студентов трёх категорий к выполнению самостоятельной работы;

-разрабатывать банк заданий для организации аудиторной и внеаудиторной самостоятельной работы трёх категорий студентов;

-использовать различные формы педагогического взаимодействия, то есть взаимодействия преподавателя со студентами трёх категорий;

-применять различные методы, виды и формы контроля самостоятельной работы студентов трёх категорий.

Прежде всего, при регулировании самостоятельной работы студентов необходимо опираться на психологические возможности «широко предметно ориентированных», «узко предметно ориентированных» и «предметно неориентированных». При организации иноязычной коммуникативной учебно-профессиональной деятельности в техническом вузе на старших ступенях бакалавриата (III-IV курсах) вопрос, касающийся индивидуально-дифференцированного обучения, не перестаёт быть актуальным. Индивидуально-психологические характеристики личности студентов являются непосредственными источниками многообразия факторов успеваемости или отставания в учебной работе на любом образовательном уровне.

\section{Литература}

1. Афонина М.В. Формирование готовности старшеклассников к самостоятельной работе при профильном обучении: автореф. дис. ... канд. пед. наук: 13.00.01. Ижевск, 2006. - 20 с.

2. Бурлачук Л.Ф. Психодиагностика: учебник для вузов. - СПб.: Питер, 2005. $351 \mathrm{c}$.

3. Галкина И.А. Организация педагогического взаимодействия преподавателя и студентов в процессе изучения иностранного языка (на материале технического вуза): автореф. дис. ... канд. пед. наук. - Новокузнецк, 2008. - 24 с.

4. Зимняя И.А. Педагогическая психология. - Ростов-на-Дону: Феникс, 1997. $480 \mathrm{c}$.

5. Кудрявцев Т.В., Шегурова В.Ю. Психологический анализ динамики профессионального самоопределения личности // Вопросы психологии. - 1983. - № 2. С. 51-59.

6. Осницкий А.К. Проблемы исследования субъективной активности // Вопросы психологии. - 1996. - № 1. - С. 5-19.

7. Тюрикова Г., Филатова О., Прошкина И., Ильина Ю., Семёнова Е. Организация самостоятельной работы студентов - условие реализации компетентностного подхода // Высшее образование в России. - 2008. - № 10. - С. 93-97.

8. Шаламов В.В. Организация самостоятельной работы в образовательных учреждениях. Историческая наука и историческое образование на рубеже XX-XXI столетий // Четвёртые всероссийские историко-педагогические чтения. - Екатеринбург: УрГПУ, Банк культурной информации, 2000. 